\title{
EFFECTS OF Glomus mosseae AND Pseudomonas fluorescens ON ECO- PHYSIOLOGICAL TRAITS AND ANTIOXIDANT PRODUCTION OF MUNG BEAN UNDER DROUGHT CONDITION
}

\author{
Mohammad SALEHI ${ }^{1}$, Ali FARAMARZI*I, Manoochehr FARBOODI ${ }^{2}$, \\ Nasser MOHEBALIPOUR ${ }^{\prime}$, Jalil AJALLI ${ }^{l}$ \\ ${ }^{1}$ Islamic Azad University, Department of Agronomy and Plant Breeding, Miyaneh Branch, \\ Miyaneh, IRAN \\ ${ }^{2}$ Islamic Azad University, Department of Soil Science, Miyaneh Branch, Miyaneh, IRAN \\ *Corresponding author: aliifaramrzii52@gmail.com
}

Received: 06.12.2019

\begin{abstract}
Drought is one of the most critical environmental stressors affecting agricultural productivity around the world and it considerably results in yield. Symbiosis interaction between plants and soil micro-organisms are considered to enhance plant tolerance in a/biotic conditions. In this study, the impact of Glomus mosseae, Pseudomonas fluorescens strain 169 and both of them under imposed water stress (flowering and pod filling stages) of mung bean (Vigna radiata (L.) Wilczek) was evaluated in two farm experiments during 2016 and 2017. Eco-physiological parameters have been recorded which showed that drought stress reduced the number of leaves, root colonization and seeds yield of mung bean. Mixed inoculation of G.mosseae and P.fluorescens 169 was more effective in alleviation the harm effects of drought stress. Enzymes assay suggested that co-inoculation of G.mosseae and P.fluorescens 169 was more effective to increase antioxidative defense system like catalase (CAT), glutathione peroxidase (GPX) and glutathione reductase (GR) activities. $\mathrm{H}_{2} \mathrm{O}_{2}$ contents were increased by water stress both in cutting irrigation at flowering and pod filling stages. In conclusion, plants inoculated with combination of G.mosseae and P.fluorescens 169 had less oxidative damage over control plants.
\end{abstract}

Key words: Glomus mosseae, Mung bean, Oxidative damage, Pseudomonas fluorescens, Root colonization, Symbiosis, Vigna radiata, Water deficit

\section{INTRODUCTION}

One of the major abiotic threats on agriculture productivity is the progressive diffusion of water deficit in different areas of the world (Dai, 2011), which induces a reduction in plant growth and development (Toker and Mutlu, 2011). Drought has a negative impact on nutrient supply, leading to a decrease in phosphate availability (Sardans and Peñuelas, 2004). Although drought impedes on wheat (Triticum aestivum L.) and barley (Hordeum vulgare L.) performance in all growth stages, it is more critical during the flowering and grain-filling phases (terminal drought) and results in substantial yield losses. (Toker et al., 2009; Farooq et al., 2014). Ganbari and Mollashahi Javan (2015) suggested that irrigation in pod filling stage improved final seed yield of mung bean (Vigna radiata (L.) Wilczek). Among the studies on drought, great interest has been developed in the last years to beneficial soil micro-organisms, including arbuscular mycorrhizal fungi (AMF) with a role to improve plant nutrition and tolerance to several environmental stresses. AM symbiosis is one of the most ancient interactions between the roots of more than $80 \%$ of terrestrial plants, including several crops
(Balestrini and Lumini, 2018). AM fungi can promote plants performance and protect them from various stresses, including water deficit (Lenoir et al., 2016; Balestrini and lumini, 2018). Some of the bacterial strains mitigating biotic stresses have also been shown to protect plants against abiotic stresses and promote plant growth by improving soil structure and moisture retention as well as by enhancing plant mineral-nutrition absorption (Bashan et al., 2013; Kim et al., 2012). Treatment with Pseudomonas fluorescens enhanced the growth parameters of Catharanthus roseus under drought stress and partially ameliorated the drought induced growth inhibition by increasing the fresh and dry weights significantly (Abdul Jaleel et al., 2007). Microbial communities below the ground influence the selection on plant traits by mitigating the effects of abiotic stress on plant population (Lau and Lennon, 2011). Manipulation of below-ground microbial communities showed that Brassica rapa grown in soils with simplified microbial communities were smaller, with reduced chlorophyll content, fewer flowers, and less fecund when compared with plants population grown in association with more complex soil microbial communities 
(Lau and Lennon, 2011). AMF and bacteria can interact synergistically to stimulate plant growth through a range of mechanisms that include improved nutrient acquisition (Barea et al., 2002) and enhancement of root branching (Gamalero et al., 2004). Only a few strains of bacteria with mycorrhizal fungi can be used effectively and show synergistic effects (Ruiz-Lozano and Bonfante, 2001). The performance of flaxseed (Linum usitassimum L.) partially enhanced by microbial dual inoculations as well as mycorrhizal and/or phosphate solubilizing bacteria (Rahimzadeh and Pirzad, 2019). Bianciotto et al. (1996) reported that some Rhizobium and Pseudomonas species attached to germinated AM fungal spores and hyphae under sterile conditions, and that the degree of attachment varied from the bacterial strains. Therefore, some microorganisms, named mycorrhiza helper bacteria (MHB) can facilitate establishment and the functioning of AMF symbiosis by stimulating spore germination, mycelial growth, root colonization or sporulation, but also by reducing stresses that could impact on AMF symbiosis (Leis et al., 2018).

Activated oxygen compound produced in different compartments of the plant cell such as the chloroplast, mitochondria and peroxisomes for example $\mathrm{H}_{2} \mathrm{O}_{2}, \mathrm{O}_{2}{ }^{-}$, and $\mathrm{OH}^{-}$may accumulate during water deficit stress and damage the photosynthetic apparatus. Oxidative molecules initiate damage in the chloroplast and cause a cascade of damaging effect including chlorophyll destruction, lipid peroxidation and protein loss (Zhang and Kirkham, 1994). $\mathrm{H}_{2} \mathrm{O}_{2}$ and malondialdehyde levels were increased by water stress both in arbuscular mycorrhizal and non-mycorrhizal plants, but this increment was significantly highest in NMplants (Mohamed et al., 2014). More researches approved that there is strong and significant relationship between different oxidative damages caused by environmental stresses and increment in antioxidant activities in photosynthetic plants (Heidari and Golpaygani, 2011). Antioxidative enzymes like catalase (CAT), glutathione peroxidase (GPX) and glutathione reductase (GR) are the most important components in the scavenging system of reactive oxygen species (Notor and Foyer, 1998; Rasool et al., 2013). Catalase (CAT) activity was higher under drought stress in mycorrhized plants than those of nonmycorrhizal ones and mixed AMF inoculation had more beneficial effect on plant growth than single AMF inoculation (Zhang et al., 2019).The differences of this study from previous ones is offering new insights for understanding the physiological mechanisms involved in tolerance toward water deficit as mediated by G.mosseae and P.fluorescens 169 and a way that mung bean uses to scavenge ROS by enhancing the antioxidant enzymes. We hypothesized that co-inoculation of fungous and bacterium with distinct properties at specific stages of plant development would enhance plant performance.

\section{MATERIALS AND METHODS}

Two factorial experiments based on Randomized Complete Block Design with three replications conducted in research and training field of Islamic Azad University, Miyaneh Branch, Iran $\left(37^{\circ}, 55^{\prime} \mathrm{N}\right.$; $47^{\circ}, 11^{\prime} \mathrm{W}$; elevation $1100 \mathrm{~m}$ ) in 2016 and 2017. Experimental plots were drought stress which included; stopping irrigation in flowering stage $\left(D_{1}\right)$, stopping irrigation in pod setting stage $\left(\mathrm{D}_{2}\right)$ and normal irrigation (control). In order to calculate the amount of irrigation we used Washington State College (WSC) flume type 3 method which was about $5760000 \mathrm{~L} / \mathrm{ha}$. Inoculations as a second factor were included; non-inoculation (Control), inoculation with G.mosseae, P.fluorescens strain 169 and combination of $G$. mosseae $+P$. fluorescens strain 169 .

Partow cultivar of Mung bean was used in this study, which was provided from Seed and Plant improvement Institute, Karaj, Iran. Suspension solution of P. fluorescens strain 169 with $10^{8}-10^{9}$ live and active bacteria per $\mathrm{ml}$ $\left(\mathrm{CFUml}^{-1}\right)$ was provided from Water and Soil Research Institute, Karaj, Iran. G.mosseae was provided from Turan Biotech Company, Iran. It had approximately 330 fungi spores per gram soil and was produced by culturing in host plant which used in form of soil mixed spores and hyphae. Partow cultivar of mung bean was sown in 6 rows, $3 \times 1.5$ $\mathrm{m}^{2}$, with $50 \mathrm{~cm}$ inter-row spacing. All agricultural practices done in farm were based on Miyaneh agriculture department guideline. The results of soil physical and chemical analysis of research area indicated that soil structure was clay and amount of organic carbon, nitrogen, phosphorous and potassium in experimental farm were $1.5 \%, 0.1 \%, 5.70 \mathrm{ppm}$ and $301 \mathrm{ppm}$ respectively. During the experiment, according to soil physical and chemical analysis, substances as a sufficient amount of fertilizer including super triple phosphate $100 \mathrm{~kg} / \mathrm{ha}$ and sulphate potassium $200 \mathrm{~kg} / \mathrm{ha}$ were applied. Monthly total rainfall, average temperatures and atmospheric humidity were given in 2016 and 2017 (Table 1). 
Table1. Climate data of the experimental cite in 2016 and 2017.

\begin{tabular}{lccccc}
\hline \multirow{2}{*}{ Parameters } & \multicolumn{3}{c}{ Months } \\
\cline { 2 - 6 } & August & July & June & May & Years \\
\hline Average temperature $\left({ }^{\circ} \mathrm{C}\right)$ & 28.6 & 29.2 & 26.2 & 21.2 \\
Monthly total rainfall $(\mathrm{mm})$ & 3.10 & 0 & 0.4 & 8.3 & 2016 \\
Average atmospheric humidity $(\%)$ & 36 & 40 & 34 & 34 & 17.6 \\
\hline Average temperature $\left({ }^{\circ} \mathrm{C}\right)$ & 27.1 & 31.4 & 25.2 & 4.4 & 2017 \\
Monthly total rainfall $(\mathrm{mm})$ & 5 & 0 & 9.4 & 41 \\
Average atmospheric humidity $(\%)$ & 49 & 31 & 39 & \\
\hline
\end{tabular}

Source: Synoptic and Meteorological station of Miyaneh city, Iran

For data collection, the number of leaves were recorded according to sampling of ten plants per plot and seed yield were calculated from central rows of each plot after removing margin lines and then converted to $\mathrm{kg}$ per hectare.

To determine phosphorous concentration of seeds after sampling and drying by means of Benton (2001) method then coloring by spectrophotometer and Vanadatemolybdate calculated based on equation (1).

$$
\mathrm{P}(\%)=(\mathrm{a}-\mathrm{b}) \times(\mathrm{V} / 2000 \mathrm{w}) \times(100 / \mathrm{D} . \mathrm{M})
$$

a is concentration of phosphorous in sample ( $\mathrm{mg} / \mathrm{lit})$,

b is concentration of phosphorous in control (mg/lit),

$\mathrm{V}$ is final volume of extraction in digestion time $(\mathrm{ml})$,

$\mathrm{W}$ is dry seed weight used in digestion ( $\mathrm{ml}$ ) and

D.M is seed dry matter percentage.

Relative water content of leaves: According to Steven et al., (1990) and by means of formula 2, calculated:

$$
\mathrm{RWC}=(\mathrm{Fw}-\mathrm{Dw} / \mathrm{Sw}-\mathrm{Dw}) \times 100
$$

Where $\mathrm{Fw}$ is fresh weight,

Dw is drought weight and

$\mathrm{Sw}$ is saturated weight.

Chlorophyll content of leaves: from the last leaves of plant and by means of Spad-502 measured and noted.

Root colonization: To determinate root colonization percentage Giovannetti and Mosse (1980) method is used. Based on this method the painted root of plants distributed in a petri dishes which contains square grids then observed under binocular and the number of intersections with vertical and horizontal lines determined. Among these cross-sections, those with colonized root sections counted separately and obtained in a fraction of the total intersections based on Equation (3):

Root colonization $=$ the number of micorrhizal root intersections with grid/ the number of all intersections between root and grid $\times 100$

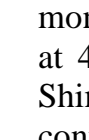
at $410 \mathrm{~nm}$ with a UV/Vis spectrophotometer (UV-1800, Shimadzu, Japan) according to a standard curve. The content of $\mathrm{H}_{2} \mathrm{O}_{2}$ was expressed as $\mu$ mol g- $\mathrm{g}^{-1} \mathrm{FW}$. GPX 
activity was assayed according to the method described by Hemeda and Klein (1990). A $100 \mathrm{~mL}$ of reaction mixture contained $10 \mathrm{~mL}$ of $1 \%$ guaiacol (v/v), $10 \mathrm{~mL}$ of $0.3 \% \mathrm{H}_{2} \mathrm{O}_{2}$ and $80 \mathrm{~mL}$ of $50 \mathrm{mM}$ phosphate buffer $(\mathrm{pH}=6.6) .75 \mu \mathrm{L}$ of enzyme extract was added to reaction mixture with a final volume of $3 \mathrm{~mL}$. An increase in absorbance due to guaiacol oxidation was monitored at $470 \mathrm{~nm}$ for $3 \mathrm{~min}$ and enzyme activity was expressed as $\mathrm{U} \mathrm{g}^{-1} \mathrm{FW} \mathrm{min}^{-1}$.

First Kolmogorov-Smirnov test was used to check for data normality and the Levene test for homogeneity of variance in SPSS for windows 7. All the original datasets was found to be conformed to a normal distribution. When necessary, depend variables were transformed using the natural logarithmic to achieve requirements of homogeneity of variance $(\mathrm{P}<0.05)$. Analysis of data was performed using SPSS software and Duncan mean comparison at level of 5\% (Produced by SPSS Inc., it was acquired by IBM in 2009, Version 16). From office software collection (2013) Excel program used to draw figures.

\section{RESULTS AND DISCUSSION}

Eco - physiological assay

Compounded variance analysis of traits displayed that based on the number of leaves per plant, the main effects of year, drought stress and the effects of inoculation, drought stress $\times$ inoculation were significant $(\mathrm{P}<0.05$ and $\mathrm{P}<0.01$ respectively) (Table 2). According to interaction effects of drought $\times$ inoculation, the highest and lowest number of leaves in plant were obtained in control plus G. mosseae and in cutting irrigation in pod filling stage plus $G$. mosseae treatments with 30.4 and 16.02 leaves respectively (Fig 1a). Drought stress reduced the number of leaves per plant and it was increased by application of $G$. mosseae by influence on physiological and biological activities of plant cells (Table 3). Reduction in plant leaves is associated with decline in cell magnitude and increase aging of leaves under water stress condition. Leaf growth and leaf surface was significantly reduced with water deficiency (Table 3 ). In order to overcome these effects, plants develop antioxidant defense systems comprising both enzymatic and non-enzymatic components that serve to prevent ROS accumulation and alleviate the oxidative damage occurring during drought stress (Miller et al., 2010).

Chlorophyll content of leaves under stopping irrigation in pod filling stage was $17.60 \%$ higher than control plants (Table 3). G.mosseae and P.fluorescens 169 had high and insignificant effect on increasing the Chlorophyll content of mung bean. Combination of G.mosseae and P.fluorescens 169 increased chlorophyll content of plants with $1.79 \%$ over control plants (Table 3 ). AMF enhances photosynthetic rate, stomata conductance and water use efficiency of Leymus chinensis by $63 \%, 38 \%$ and $15 \%$ respectively (Li et al., 2019).

Relative of water content (RWC) has been introduced as a useful indicator of the equilibrium of plant 's water. Measurements of water use efficiency provide a combination of water use rates and then allow more discussion about plant relationships when water is limited. The results of combined analysis of variance showed that the effect of year on drought stress based on relative water content was significant $(\mathrm{P}<0.05)$ (Table 2). The lowest relative water content obtained from imposed drought stress in flowering stage in 2016 with average $39.9 \%$ (Table 3). Reduction in relative water content of leaves by imposing drought stress reported by Moghadasan et al., (2016) and Aliasgharzad et al., (2006). It seems that decreasing the relative leaf content due to water shortage is related to the closure of stomata by releasing abscisic acid hormone so that under drought stress condition it is produced in root cells and accumulated in stomata cells (Khan et al., 2008).

Combined analysis of variance showed that the differences between the main level of year and bilateral effects of year $\times$ replication and year $\times$ inoculation and between the effects of inoculations were significant $(\mathrm{P}<0.05)$ in term of seed phosphorous (Table 2). The maximum amount of phosphorous was observed in plants inoculated with $G$. mosseae $(68.19 \%)$ which was higher than controlled plants and other treatments (Table 3). In 2017 inoculation by G.mosseae had more efficiency to increase seed phosphorous level as compared with 2016 (Table 3). It seems that the reduction of moisture stored in the soil, the volume and extension of roots in the soil and availability of nutrients in the soil in 2016 was higher than 2017. Therefore, accumulation of phosphorous decreased in 2016. Increasing the amount of phosphorous in seeds inoculated by mycorrhiza species was also reported by Kirda (2002).

Source of variance of traits displayed significant differences between main levels of year, drought stress and interaction effects of year $\times$ inoculation $(\mathrm{P}<0.01)$ (Table 2). Imposed drought stress reduced final seed yield of mung bean. The lowest amount of seed yield obtained in stopping irrigation in pod filling stage with average of $391.4 \mathrm{~kg} / \mathrm{ha}$ (Table 3 ). According to effects of year $\times$ inoculation, inoculation of plant by G.mosseae in 2017 caused the highest seed yield with average of $665 \mathrm{~kg} / \mathrm{ha}$. High nutrients availability of plant due to high growth and root colonization was the main mechanism to improve seed yield of mung bean in drought stress condition (Moradi et al., 2011). Co inoculation of $G$. mosseae and $P$. fluorescens 169 was more effective to increase seed yield in water deficiency condition in comparison with control treatment. Pseudomonas is one of the most important bacteria strain to increase plant growth under drought condition (Nori et al., 2016).

Variance analysis of traits resulted that differences between main levels of drought stress and inoculation based on root colonization was significant $(\mathrm{P}<0.01)$ (Table $2)$. Root colonization percentage of plants in normal irrigation condition was high with average of $56.29 \%$. (Table 3). Inoculation by both $G$. mosseae and $P$. fluorescens 169 caused the highest root colonization in 2017 (Table 3 and Fig 1b). When plant is growing actively, colonization of root by arbuscular mycorrhiza increased. Plants inoculated by $G$. mosseae had the highest root 
colonization percentage (by $61.94 \%$ ). In drought imposed condition plants inoculated by both $G$. mosseae and $P$. fluorescens 169 was more effective to increase root colonization of mung bean (Table 3 ). The differences in root colonization of mung bean in 2016 and 2017 was due to significant reduction in germination and hyphae growth. In all, plants with high root colonization had high efficiency to uptake water, phosphorous and consequently increased seed yield.

Table 2. Significant of mean squares (F values) of eco-physiological traits of mung bean

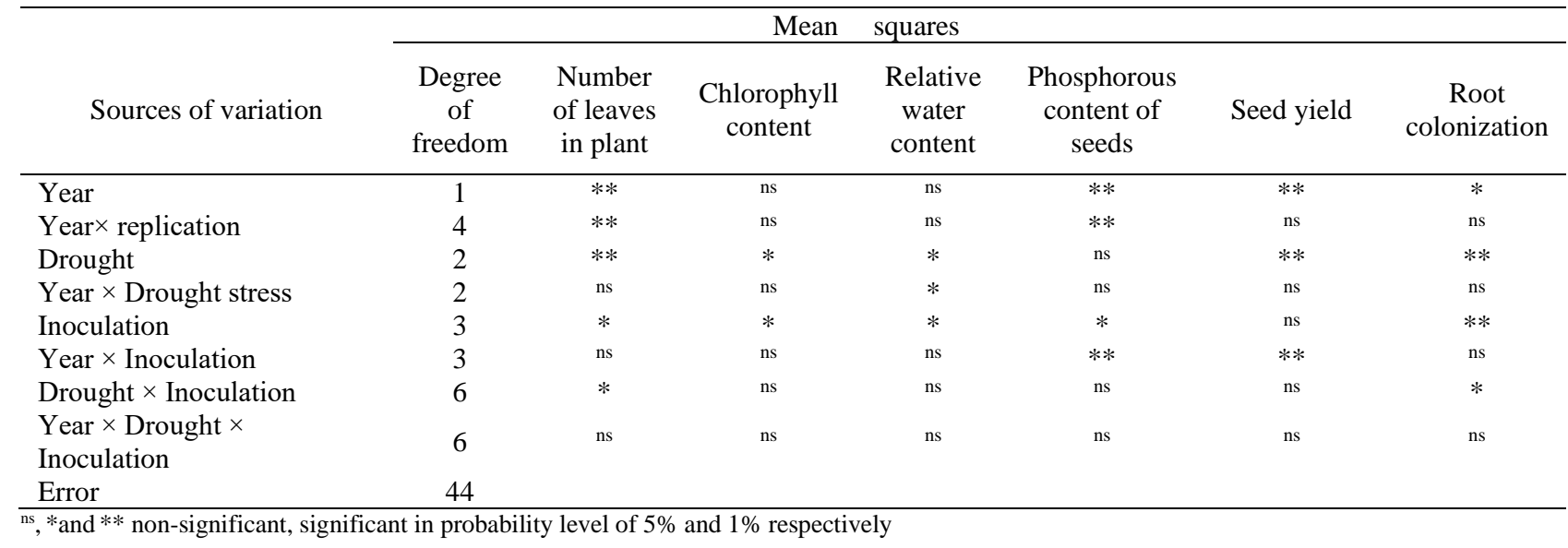

Table 3. Mean comparison of eco-physiological traits of mung bean

\begin{tabular}{|c|c|c|c|c|c|c|}
\hline $\mathrm{P}_{\text {Variables }}^{\text {Traits }}$ & $\begin{array}{l}\text { Number } \\
\text { of leaves } \\
\text { per plant }\end{array}$ & $\begin{array}{l}\text { Chlorophyll } \\
\text { content }\end{array}$ & $\begin{array}{l}\text { Relative } \\
\text { water } \\
\text { content } \\
(\%) \\
\end{array}$ & $\begin{array}{l}\text { Phosphorous } \\
\text { content of } \\
\text { seed }(\%)\end{array}$ & $\begin{array}{c}\text { Seed } \\
\text { yield } \\
(\mathrm{kg} / \mathrm{ha})\end{array}$ & $\begin{array}{c}\text { Root } \\
\text { colonization } \\
(\%)\end{array}$ \\
\hline \multicolumn{7}{|c|}{ Year } \\
\hline 2016 & $23.6^{\mathrm{a}}$ & $47.2^{\mathrm{a}}$ & $50.6^{\mathrm{a}}$ & $9.7^{\mathrm{b}}$ & $379.2^{\mathrm{b}}$ & $37.9^{\mathrm{b}}$ \\
\hline 2017 & $18.01^{\mathrm{b}}$ & $49.8^{\mathrm{a}}$ & $49.8^{\mathrm{a}}$ & $23.07^{\mathrm{a}}$ & $564.7^{\mathrm{a}}$ & $58.8^{\mathrm{a}}$ \\
\hline \multicolumn{7}{|c|}{ Drought } \\
\hline Normal irrigation (control) & $25.2^{\mathrm{a}}$ & $46.30^{c}$ & $46^{\mathrm{c}}$ & $18.32^{\mathrm{a}}$ & $577.9^{a}$ & $56.29^{\mathrm{a}}$ \\
\hline $\begin{array}{l}\text { Stopping-irrigation in flowering } \\
\text { stage }\left(D_{1}\right)\end{array}$ & $20.7^{\mathrm{ab}}$ & $50.2^{\mathrm{b}}$ & $50.51^{\mathrm{b}}$ & $15.25^{\mathrm{a}}$ & $446.5^{\mathrm{b}}$ & $45.84^{\mathrm{b}}$ \\
\hline $\begin{array}{l}\text { Stopping-irrigation in pod setting } \\
\text { stage }\left(D_{2}\right)\end{array}$ & $16.4^{\mathrm{b}}$ & $54.1^{\mathrm{a}}$ & $54.1^{\mathrm{a}}$ & $15.61^{\mathrm{a}}$ & $391.4^{\mathrm{c}}$ & $42.94^{\mathrm{b}}$ \\
\hline \multicolumn{7}{|l|}{ Inoculations } \\
\hline Non-inoculation & $18.87^{\mathrm{b}}$ & $45.2^{\mathrm{c}}$ & $47.4^{\mathrm{d}}$ & $15.27^{b}$ & $481.7^{\mathrm{a}}$ & $41.40^{c}$ \\
\hline Glomus mosseae & $22.28^{\mathrm{a}}$ & $50.6^{\mathrm{a}}$ & $50.09^{\mathrm{b}}$ & $19.68^{\mathrm{a}}$ & $485.8^{\mathrm{a}}$ & $51.66^{\mathrm{b}}$ \\
\hline Pseudomonas fluorescens 169 & $22.30^{\mathrm{a}}$ & $52.1^{\mathrm{a}}$ & $54.2^{\mathrm{a}}$ & $14.49^{b}$ & $453.02^{\mathrm{b}}$ & $40.26^{\mathrm{c}}$ \\
\hline G. mosseae + P. fluorescens 169 & $19.81^{\mathrm{b}}$ & $46.01^{\mathrm{b}}$ & $49.1^{\mathrm{c}}$ & $16.15^{\mathrm{b}}$ & $467.2^{\mathrm{b}}$ & $60.11^{\mathrm{a}}$ \\
\hline
\end{tabular}

In each column the same letter (s) indicates non-significant difference among treatments (Duncan's test, $\mathrm{P}<0.05$ ) 

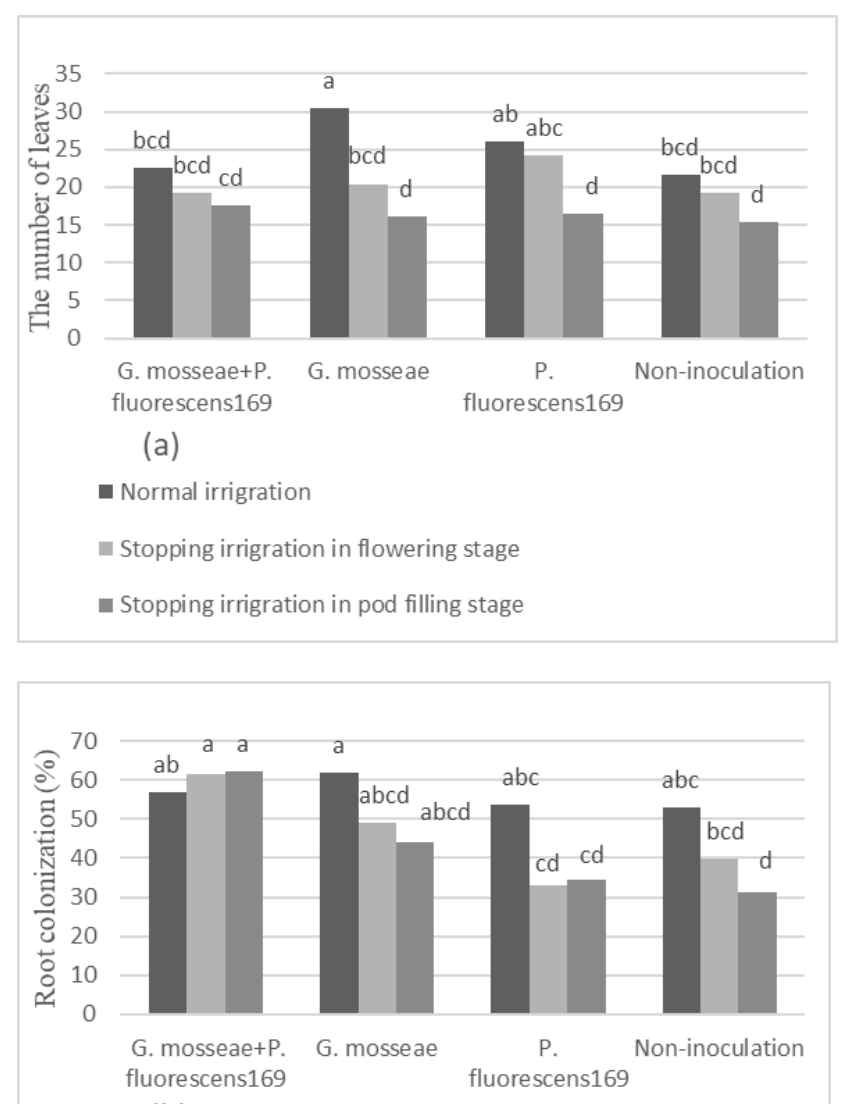

(b)

Fig 1. Comparison of the number of leaves (a), root colonization (b) based on interaction effects of drought and inoculation treatments. Means followed by same letter (s) are not significantly different at Duncan's 5\%.

\section{Antioxidant ssay}

According to Table 4, there were high and significant differences between Catalase activities (CAT) of plants based on main effects of year, drought, inoculation and interaction effects of drought $\times$ inoculation $(\mathrm{P}<0.01)$. CAT in plants inoculated with both $G$. mosseae plus $P$. fluorescens 169 was higher than single inoculated treatments. Co-inoculation of G.mosseae and $P$. fluorescens 169 enhanced catalase activity about $41.28 \%$ as compared to the control plants (Table 6). CAT of plant by imposing drought stress increased. But, the highest value was observed in imposing drought stress at flowering stage which was higher than in control plants (Table 5). CAT in all inoculated plants under different water stresses was higher than non-inoculated plants (Fig 2a). Synergistic effect of G.mosseae and P.fluorescens 169 in stopping irrigation at flowering stage caused $141.3 \%$ increase in catalase activity in comparison with control plants (Table 6). CAT is a major enzyme detoxifying hydrogen peroxide under water stress (Heidari and Golpayegani, 2011; Mittler, 2002).
Inoculation had significantly an effect on GR activity of mung bean leaves (Table 4). The effect of G.mosseae increasing GR activity of mung bean was 2 fold of $P$. fluorescens 169 as compared with non-inoculated plants. However, inoculation with both G.mosseae plus P.fluoresens 169 caused the highest GR activity of leaves (Table 5). Two year field experiments showed that inoculation with both G.mosseae and P.fluorescens 169 induced GR activity of leaves and this increase in 2017 was about $9.09 \%$ higher than in 2016 (Table 6). GR enzyme activity showed that amount of this enzyme by cutting irrigation in flowering stage and pods filling stage treatment plots were $81.09 \%$ and $63.02 \%$ respectively as compared with normal irrigated plants (Table 5). Combination of G.mosseae and P.fluorescens 169 enhanced GR activity in the leaves of plants in cutting irrigation in flowering stage (Fig 2b). Glutathione reductase plays an important role in adaptation to oxidative stress. This enzyme (GR) is responsible for conversion of oxidized glutathione to reduced glutathione and maintain a high ration of GSH to GSSG. Glutathione in Xanthophyll, Mehler and Ascorbate- Glutathione cycles has the main role on hydrogen peroxide collection and preservation of GSH. Hence, increased GR due to restoration of oxidized glutathione is very important (Sairam et al., 2003).

Hydrogen peroxide $\left(\mathrm{H}_{2} \mathrm{O}_{2}\right)$ content of leaves significantly decreased in inoculated plants as compared with non-inoculated ones. This reduction in plants inoculated by P.fluorescens 169 was the highest while G.mosseae and combination of G.mosseae plus P.fluorescens 169 had the same effect on $\mathrm{H}_{2} \mathrm{O}_{2}$ decline (Table 5). In addition, the efficiency of P.fluorescens 169 in reduction of $\mathrm{H}_{2} \mathrm{O}_{2}$ was $41.6 \%$ and $21.4 \%$ higher than control and other inoculated treatments, respectively (Table $5)$.

$\mathrm{H}_{2} \mathrm{O}_{2}$ content of leaves was increased by imposing drought stress. Stopping irrigation in pod filling stage caused the highest $\mathrm{H}_{2} \mathrm{O}_{2}$ content of leaves by $44.96 \%$ as compared with control plants (Table 5). According to Fig $2 \mathrm{c}$, non-inoculated plants in all drought stressed treatments had the highest average of hydrogen peroxide content. This result indicates that inoculation with G.mosseae, P.fluorescens 169 and both could help plants to reduce the oxidative damage caused by drought stress.

Imposing drought stress by stopping irrigation in both flowering and pod filling stages significantly increased GPX activity over the control (Table 5). Inoculation treatments had significant effect on the activity of GPX. Thus, mix inoculation by G.mosseae and P.fluorescens 169 caused the highest GPX by $134.61 \%$ (Table 5). Based on interaction effects of inoculation and drought stress, the synergistic effect of G.mosseae and P.fluorescens 169 under stopping irrigation in pod filling stage induced the highest GPX enzyme activity (Fig 2d). 
Table 4. Mean squares of measured antioxidative enzymes and $\mathrm{H}_{2} \mathrm{O}_{2}$ of mung bean

\begin{tabular}{|c|c|c|c|c|c|}
\hline \multirow[b]{2}{*}{ S.O.V } & \multirow[b]{2}{*}{$\frac{t}{t}$} & \multicolumn{4}{|c|}{ Mean squares } \\
\hline & & 艺 & 絪 & $\begin{array}{l}O^{\prime} \\
\Xi\end{array}$ & $\underset{0}{凶}$ \\
\hline Year & 1 & $* *$ & $* *$ & $* *$ & $* *$ \\
\hline Year $\times$ replication & 4 & ns & ns & $* *$ & ns \\
\hline Drought & 2 & $* *$ & $* *$ & $* *$ & $* *$ \\
\hline Year $\times$ Drought stress & 2 & ns & $* *$ & $* *$ & $* *$ \\
\hline Inoculation & 3 & $* *$ & $* *$ & $* *$ & $* *$ \\
\hline Year $\times$ Inoculation & 3 & ns & $* *$ & $*$ & $* *$ \\
\hline Drought $\times$ Inoculation & 6 & $* *$ & $* *$ & $* *$ & $* *$ \\
\hline Year $\times$ Drought $\times$ Inoculation & 6 & ns & $*$ & ns & $* *$ \\
\hline Error & 44 & & & & \\
\hline Coefficient of variation (\%) & & 0.98 & 7.15 & 5.05 & 5.40 \\
\hline
\end{tabular}

Table 5. Mean comparison of measured antioxidative enzymes and $\mathrm{H}_{2} \mathrm{O}_{2}$ based on inoculation and drought

\begin{tabular}{|c|c|c|c|c|}
\hline Inoculation & $\begin{array}{c}\mathrm{CAT} \\
\left(\mathrm{Ug}^{-1}\right. \\
\left.\mathrm{FWmin}^{-1}\right)\end{array}$ & $\begin{array}{c}\mathrm{GR} \\
\left(\begin{array}{c}\mathrm{Ug}^{-1} \text { protein } \\
\left.\min ^{-1}\right)\end{array}\right.\end{array}$ & $\begin{array}{c}\mathrm{H}_{2} \mathrm{O}_{2} \\
(\mu \mathrm{mol})\end{array}$ & $\begin{array}{c}\text { GPX } \\
\left(\mathrm{Ug}^{-1} \mathrm{FW} \min ^{-1}\right)\end{array}$ \\
\hline Non-inoculation & $16.81^{\mathrm{d}}$ & $0.18^{\mathrm{d}}$ & $0.24^{a}$ & $0.26^{\mathrm{d}}$ \\
\hline Glomus mosseae & $22.35^{\mathrm{b}}$ & $0.36^{\mathrm{b}}$ & $0.17^{\mathrm{b}}$ & $0.49^{\mathrm{b}}$ \\
\hline Pseudomonas fluorescens 169 & $20.05^{\mathrm{c}}$ & $0.27^{\mathrm{c}}$ & $0.14^{\mathrm{c}}$ & $0.38^{\mathrm{c}}$ \\
\hline G. mosseae+ P. fluorescens 169 & $23.75^{\mathrm{a}}$ & $0.57^{\mathrm{a}}$ & $0.17^{\mathrm{b}}$ & $0.61^{\mathrm{a}}$ \\
\hline Drought & CAT & GR & $\mathrm{H}_{2} \mathrm{O}_{2}$ & GPX \\
\hline Normal irrigation & $15.37^{\mathrm{c}}$ & $0.238^{\mathrm{c}}$ & $0.149^{c}$ & $0.240^{\mathrm{b}}$ \\
\hline Stopping irrigation in flowering stage $\left(\mathrm{D}_{1}\right)$ & $23.75^{\mathrm{a}}$ & $0.431^{\mathrm{a}}$ & $0.189^{\mathrm{b}}$ & $0.529^{\mathrm{a}}$ \\
\hline Stopping irrigation in pod filling stage $\left(\mathrm{D}_{2}\right)$ & $23.10^{\mathrm{b}}$ & $0.388^{\mathrm{b}}$ & $0.216^{\mathrm{a}}$ & $0.544^{\mathrm{a}}$ \\
\hline
\end{tabular}

In each column the same letter (s) indicates non-significant difference among treatments (Duncan`s test, $\mathrm{P}<0.05$ ).

Catalase (CAT), Glutathione reductase (GR), hydrogen peroxidase $\left(\mathrm{H}_{2} \mathrm{O}_{2}\right)$, glutathione peroxidase (GPX).

Table 6. Mean comparison of measured antioxidative enzymes and $\mathrm{H}_{2} \mathrm{O}_{2}$ based on interaction effect of year $\times$ inoculation and year $\times$ drought

\begin{tabular}{|c|c|c|c|c|}
\hline Year & Inoculation & $\begin{array}{c}\mathrm{GR} \\
\left(\begin{array}{c}\mathrm{Ug}^{-1} \text { protein } \\
\left.\min ^{-1}\right)\end{array}\right.\end{array}$ & $\begin{array}{c}\mathrm{H}_{2} \mathrm{O}_{2} \\
(\mu \mathrm{mol})\end{array}$ & $\begin{array}{c}\text { GPX } \\
\left(\mathrm{Ug}^{-1} \mathrm{FW} \text { min }^{-}\right. \\
1)\end{array}$ \\
\hline \multirow{4}{*}{2016} & Non-inoculation & $0.18^{\mathrm{e}}$ & $0.24^{\mathrm{a}}$ & $0.35^{\mathrm{e}}$ \\
\hline & Glomus mosseae & $0.32^{\mathrm{bc}}$ & $0.20^{\mathrm{b}}$ & $0.65^{\mathrm{b}}$ \\
\hline & Pseudomonas fluorescens 169 & $0.24^{\text {cde }}$ & $0.15^{\mathrm{d}}$ & $0.51^{\mathrm{c}}$ \\
\hline & G. mosseae+ P. fluorescens 169 & $0.55^{\mathrm{a}}$ & $0.18^{\mathrm{c}}$ & $0.78^{\mathrm{a}}$ \\
\hline \multirow{5}{*}{2017} & Non-inoculation & $0.19^{\mathrm{de}}$ & $0.25^{\mathrm{a}}$ & $0.17^{\mathrm{h}}$ \\
\hline & Glomus mosseae & $0.41^{\mathrm{b}}$ & $0.14^{\mathrm{d}}$ & $0.32^{\mathrm{f}}$ \\
\hline & Pseudomonas fluorescens 169 & $0.31^{\text {bcd }}$ & $0.12^{\mathrm{e}}$ & $0.25^{\mathrm{g}}$ \\
\hline & G. mosseae+ P. fluorescens 169 & $0.60^{\mathrm{a}}$ & $0.15^{\mathrm{d}}$ & $0.43^{\mathrm{d}}$ \\
\hline & Drought & GR & $\mathrm{H}_{2} \mathrm{O}_{2}$ & GPX \\
\hline \multirow{3}{*}{2016} & Normal irrigation & $0.199^{\mathrm{d}}$ & $0.137^{\mathrm{d}}$ & $0.318^{\mathrm{c}}$ \\
\hline & Stopping irrigation in flowering stage $\left(\mathrm{D}_{1}\right)$ & $0.424^{\mathrm{a}}$ & $0.211^{\mathrm{ab}}$ & $0.697^{\mathrm{a}}$ \\
\hline & Stopping irrigation in pod filling stage $\left(\mathrm{D}_{2}\right)$ & $0.351^{\mathrm{b}}$ & $0.246^{\mathrm{a}}$ & $0.714^{\mathrm{a}}$ \\
\hline \multirow{3}{*}{20017} & Normal irrigation & $0.277^{\mathrm{c}}$ & $0.161^{\mathrm{cd}}$ & $0.161^{\mathrm{d}}$ \\
\hline & Stopping irrigation in flowering stage $\left(\mathrm{D}_{1}\right)$ & $0.437^{\mathrm{a}}$ & $0.167^{\mathrm{cd}}$ & $0.361^{\mathrm{b}}$ \\
\hline & Stopping irrigation in pod filling stage $\left(D_{2}\right)$ & $0.426^{\mathrm{a}}$ & $0.186^{\mathrm{bc}}$ & $0.374^{\mathrm{b}}$ \\
\hline
\end{tabular}

In each column the same letter (s) indicates non-significant difference among treatments (Duncan's test, $\mathrm{P}<0.05$ ).

Glutathione reductase (GR), hydrogen peroxidase $\left(\mathrm{H}_{2} \mathrm{O}_{2}\right)$, glutathione peroxidase (GPX). 


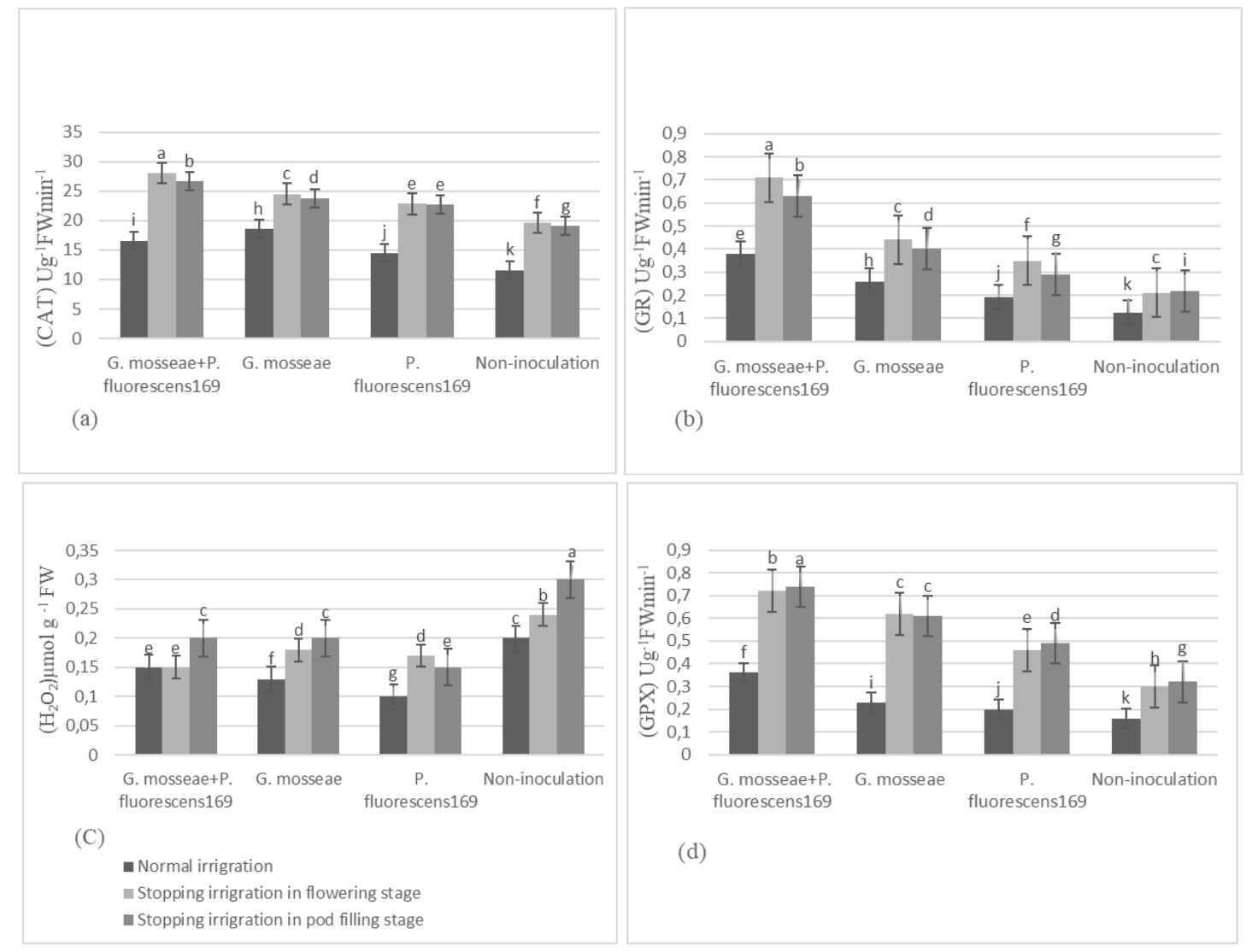

Fig 2. Mean comparison of CAT activity (a) GR activity (b) $\mathrm{H}_{2} \mathrm{O}_{2}$ content (c) and GPX activity (d) in leaves based on interaction effects of inoculation and drought stress. Means followed by same letter (s) are not significantly different at Duncan's 5\%.

\section{CONCLUSION}

Pod formation stage of mung bean was distinguished as susceptible growth stage of plant in water deficit condition. In addition, stopping irrigation in pod formation stage had high negative influence on seed yield. The synergistic effects of G. mosseae and P. fluorescens 169 increased root colonization of mung bean in irrigation condition. According to relative water content, flowering stage in 2016 was sensitive to drought stress, while relative water content of plant in drought condition was higher than normal irrigation condition in 2017. The exact mechanism for mung bean to alleviate harm effects of drought stress was through enhancement of GPX and CAT enzymes by interaction symbiosis between G.mosseae and P.fluorescens 169 rather than individual ones. It was conclude that relying on APX and GPX is the best strategy improving the tolerance of mung bean under drought stress condition. Stopping irrigation in flowering stage increased CAT, GR and GPX activity of leaves while the highest $\mathrm{H}_{2} \mathrm{O}_{2}$ content observed in plants under cutting irrigation in pod filling stage. Mixed inoculation of G.mosseae and P.fluorescens 169 had more beneficial effect on enzyme activities of mung bean under drought stressed condition. In all, the recommendation is using the combination of G.mosseae plus P.fluorescens 169 as a biological fertilizer in dry area to increase drought tolerance and seed yield of mung bean.

\section{LITERATURE CITED}

Abdul Jaleel, C., P. Manivannan, B. Sankar, A. Kishorekumar, R. Gopi, R. Somasundaram and R. Panneerselvam. 2007. Pseudomonas fluorescens enhances biomass yield and ajmalicine production in Catharanthus roseus under water deficit stress. Colloids and Surfaces B: Biointerfaces. 60 (1): 7-11. https://doi.org/10.1016/j.colsurfb.2007.05.012.

Aliasgharzad, N., M.R. Neyshabouri and G. Salimi. 2006. Effects of arbuscular mycorrhizal fungi and Bradyrhizobium japonicum on drought stress of soybean, Biologia. 67: 324328.

Balestrini, R. and E. Lumini. 2018. Focus on mycorrhizal symbioses. Appl. Soil Ecol. 123. PP: 299-304. https://DOI: 10.1016/j.apsoil.2017.09.001

Barea, J.M., R. Azcon and C. Azcon-Aguilar. 2002. Mycorhizosphere interactions to improve plant fitness and soil quality. AntonyVan Leeuwenhoek. 81: 343-351.

Bashan, Y., A.K. Kamnev and L.E. de-Bashan. 2013. Tricalcium phosphate is inappropriate as a universal selection factor for isolating and testing phosphate-solubilizing bacteria that enhance plant growth: a proposal for an alternative procedure. Biol Fertil Soils. 49: 465-479.

Benton, J.J. 2001. Laboratory guild for conducting soil test and plant analysis. 363 P.P. USA. CRC Press. P: 384.

Biancitto, V., D. Minerdi, S. Perotto and D. Bonfante. 1996. Cellular interactions between arbuscular mycorrhizal fungi and rhizosphere bacteria. Protoplasma. 193:123-137.

Dai, A. 2011. Drought under global warming: a review. Wires Clim. Chang. 2. pp: 45-5. DOI: $10.1002 /$ wcc. 81 .

Farooq, M., M. Hussain, H. Kadambot and M. Siddique. 2014. Drought stress in wheat during flowering and grain filling 
periods. Critical reviews in plant sciences. 33(4): 331349.https://DOI:10.1080/07352689.2014.875291.

Foyer, C.H. and B. Halliwell. 1976. The presence of glutathione and glutathione reductase in chloroplasts: a proposed role in ascorbic acid metabolism. Planta. 133 (1): 21-25. doi: 10.1007/BF00386001 PMID:24425174

Gamalero, E., A. Trotta, N. Massa, A. Copetta, A.G. Martinotti and G. Berta. 2004. Impact of two fluorescent pseudomonas and an arbascular mycorrhizal fungus on tomato plant growth, root architecture and $\mathrm{P}$ acquisition. Mycorrhiza.14:185-192.

Ganbari, M. and Sh. Mollashahi Javan. 2015. Study the response of mung bean genotypes to drought stress by multivariate analysis. International Journal of Agriculture Innovations and Research. 3(4): 2319-1473.

Giovannetti, M. and B. Mosse. 1980. An evaluation of technique to measure vesicular arbuscular mycorrhizal infection in roots. New Phytologist. 84: 489-500.

Heidari, M. and A. Golpayegani. 2011. Effects of water stress and inoculation with plant growth promoting rhizobacteria (PGPR) on antioxidant status and photosynthetic pigments in basil (Ocimum basilicum L.). Journal of the Saudi Society of Agricultural Sciences. (11): 57-61.

Hemeda, H.M. and B.P. Klein. 1990. Effects of naturally occurring antioxidants on peroxidase activity of vegetable extracts. J Food Sci. 55(1):184-185.

Khan, M.S., A. Ziadi, P.A. Wani and M. Oves. 2008. Role of plant growth promoting rhizobacteria in the remediation of metal contaminated soils. Environmental chemistry letters: 7: 1-19.

Kim, Y-C., B.R. Glick, Y. Bashan and C.M. Ryu. 2012. Enhancement of plant drought tolerance by microbes. In: Aroca $\mathrm{R}$ (ed) Plant responses to drought stress: from morphological to molecular features. Springer Verlag, Berlin \& Heidelberg, Germany pp, pp: 383-413.

Kirda, C. 2002. Deficit irrigation scheduling based on plant growth stages showing water stress tolerance. PP: 3-10. In FAO, water report No.22, Deficit Irrigation practices.

Lau, J.A. and J.T. Lennon. 2011. Evolutionary ecology of plantmicrobe interactions: soil microbial structure alters selection on plant traits. New Phytol. 192: 215-224.

Lenoir, I., J. Fontaine and L.H. Sahraoui. 2016. Arbuscular mycorrhizal fungal responses to abiotic stresses: a review. Phytochemistry. 123:

4-15. https://DOI:10.1016/j.phytochem.2016.01.002.

Li, J., B. Meng, H. Chai, X. Yang, W. Song, S. Li, A. Lu, T. Zhang and W. Sun. 2019. Arbuscular Mycorrhizal fungi alleviate drought Stress in $\mathrm{C}_{3}$ (Leymus chinensis) and $\mathrm{C}_{4}$ (Hemarthria altissima) grasses via altering antioxidant enzyme activities and photosynthesis. Front. Plant Sci. 10: 499. doi: 10.3389/fpls.2019.00499.

Lies, L., A. Delteil, Y. Prin and R. Duponnois. 2018. Using Mycorrhiza helper microorganisms (MHM) to improve the mycorrhizal efficiency on plant growth. In: Meena V. (eds) Role of Rhizospheric microbes in soil. Springer, Singapore. pp: 277-298. https://doi.org/10.1007/978-981-10-8402-7_11

Miller, G., N. Susuki, S. Ciftci-Yilmaz and R. Mittler. 2010. Reactive oxygen species homeostasis and signaling during drought and salinity stresses. Plant Cell Environ. 33: 453-467.

Mittler, R. 2002. Oxidative stress, antioxidants and stress tolerance. Trends Plant Sci. 7: 405-410.

Moghadasan, Sh., A. Safipour Afshar and F.S. Nematpour. 2016. The role of Mycorrhiza drought tolerance of marigold (Calendula officinalis L.). Journal of Crop Eco physiology. 9(4): 521-532.
Mohamed, O., A.E. Fouad, B. Laila and Q. Ahmed. 2014. Effectiveness of arbuscular mycorrhizal fungi in the protection of olive plants against oxidative stress induced by drought. Spanish Journal of Agricultural Research. 12(3): 763-771.

Moradi, M., A. Siadat, K. Khavazi, R. Naseri, A. Maleki and A. Mirzaei. 2011. Effect of application of bio-Fertilizer and phosphorous fertilizer on quantities and qualitative traits of spring wheat. Journal of Crop Eco physiology. 5(18): 51-66.

Nori, M.J., A. Mozafari and M. Mirzaee- Haydari. 2016. Evaluation of yield and yield components of lentil (Lens Culiuaris Medik) effected by biofertilizer, nitrogen starter and supplemental irrigation on Kermanshah province, Journal of Agronomy and plant Breeding. 12(1): 1-14.

Notor, G. and C.H. Foyer. 1998. Ascorbate and glutathione: keeping active oxygen under control. Annu. Rev. Plant Physiol. Plant Mol. Biol. 49: 249-279.

Patterson, B.D., E.A. MacRae and I.B. Ferguson. 1984. Estimation of hydrogen peroxide in plant extracts using titanium (IV). Anal Biochem. 139(2):487-492. PMID: 6476384

Rahimzadeh, S. and A.R. Pirzad. 2019. Pseudomonas and mycorrhizal fungi co-inoculation alter seed quality of flax under various water supply conditions. Industrial crops and products. 129 : 518-524. https://doi.org/10.1016/j.indcrop.2018.12.038

Rasool, S., A. Ahmad, T.O. Siddiqi and P. Ahmad. 2013. Changes in growth, lipid peroxidation and some key antioxidant enzymes in chickpea genotypes under salt stress. Acta Physiol Plant. 35: 1039-1050.

Roland, F., J.R. Beers and W.S. Irwin. 1952. A spectrophotometric method for measuring the breakdown of hydrogen peroxide by catalase. J. Biol. Chem. 195: 133-140.

Ruiz-Lozano, J.M. and P. Bonfante. 2001. Intracellular Burkholderia strain has no negative effect on the symbiotic efficiency of the arbuscular mycorrhizal fungus Gigaspora margarita. Plant Growth Regulation. 34: 347-352.

Sairam, R.K., K.V. Rao and G.C. Srivastava. 2003. Differential response of wheat genotypes to long term salinity stress in relation to oxidative stress, antioxidant activity and osmolyte concentration. Plant Science 163:1037-1046.

Sardans, J. and J. Peñuelas. 2004. Increasing drought decreases phosphorus availability in an evergreen Mediterranean forest. Plant Soil. (267): 367-377. https://DOI: 10.1007/s11104-0050172-8.

Steven, W., T. Ritchie, H. Nguyen and A.S. Holaday. 1990. Leaf water content and gas exchange parameters of two wheat genotypes differing in drought resistance. Crop Sci. 30(1):105-177.

Toker, C., and N. Mutlu. 2011. Biology and breeding of food legumes, ed. Pratap, A and J, Kumar. PP: 241-261. CABI.

Toker, C., J. Gorham and M.I. Cagirgan. 2009. Certain ion accumulations in barley mutants exposed to drought and salinity. Turkish Journal oF Field Crops 14 (2): 162-169.

Zhang, J.X. and M.B. Kirkham. 1994. Drought stress induced changes in activities of superoxide dismutase, catalase, and peroxidase in wheat species. Plant Cell Physiol. 35: 785-791.

Zhang, Z.F., J. Zhang, G. Xu, L. Zhou, and Y. Li. 2019. Arbuscular mycorrhizal fungi improve the growth and drought tolerance of Zenia insignis seedlings under drought stress. New Forests. 50(4): 50- 593. https://doi.org/10.1007/s11056-018-9681-1 